\title{
Microstructures and microwave dielectric properties of $\left(\mathrm{Ba}_{1-\mathrm{x}} \mathrm{Sr}_{\mathrm{x}}\right)_{4}\left(\mathrm{Sm}_{0.4} \mathrm{Nd}_{0.6}\right)_{28 / 3} \mathrm{Ti}_{18} \mathrm{O}_{54}$ solid solutions
}

\author{
Xianpei HUANG ${ }^{a}$, Xinyu $\mathrm{LIU}^{a}$, Fei $\mathrm{LIU}^{b, *}$, Changlai YUAN ${ }^{a, c}$, Jingjing QU ${ }^{d}$, \\ Jiwen $\mathrm{XU}^{a}$, Changrong $\mathrm{ZHOU}^{a}$, Guohua $\mathrm{CHEN}^{a}$
}

${ }^{a}$ School of Material Science and Engineering, Guilin University of Electronic Technology, Guilin 541004, China ${ }^{b}$ School of Mechanical and Electrical Engineering, Guilin University of Electronic Technology, Guilin 541004, China ${ }^{c}$ Guangxi Key Laboratory of Information Materials, Guilin University of Electronic Technology, Guilin 541004, China ${ }^{d}$ Department of Information Engineering, Guilin University of Aerospace Technology, Guilin 541004, China

Received: October 17, 2016; Revised: December 01, 2016; Accepted: December 19, 2016

(C) The Author(s) 2016. This article is published with open access at Springerlink.com

\begin{abstract}
Ba}_{1-x} \mathrm{Sr}_{x}\right)_{4}\left(\mathrm{Sm}_{0.4} \mathrm{Nd}_{0.6}\right)_{28 / 3} \mathrm{Ti}_{18} \mathrm{O}_{54}(x=0.02,0.04,0.06,0.08,0.1)$ solid solutions were prepared by the conventional solid-state reaction process. It was found that $\left(\mathrm{Ba}_{1-x} \mathrm{Sr}_{x}\right)_{4}\left(\mathrm{Sm}_{0.4} \mathrm{Nd}_{0.6}\right)_{28 / 3}$ $\mathrm{Ti}_{18} \mathrm{O}_{54}$ ceramics are fully composed of $\mathrm{BaSm}_{2} \mathrm{Ti}_{4} \mathrm{O}_{12}$ and $\mathrm{BaNd}_{2} \mathrm{Ti}_{5} \mathrm{O}_{14}$ phases for all the compositions. The increasing $x$ value $(0.02 \leqslant x \leqslant 0.1)$ in $\left(\mathrm{Ba}_{1-x} \mathrm{Sr}_{x}\right)_{4}\left(\mathrm{Sm}_{0.4} \mathrm{Nd}_{0.6}\right)_{28 / 3} \mathrm{Ti}_{18} \mathrm{O}_{54}$ ceramics can not only obtain high $Q \times f$ value but also effectively enhance the permittivity $\left(\varepsilon_{\mathrm{r}}\right)$. The $\left(\mathrm{Ba}_{1-x} \mathrm{Sr}_{x}\right)_{4}\left(\mathrm{Sm}_{0.4} \mathrm{Nd}_{0.6}\right)_{28 / 3} \mathrm{Ti}_{18} \mathrm{O}_{54}$ ceramic with $x=0.08$, sintered at $1440{ }^{\circ} \mathrm{C}$ for $4 \mathrm{~h}$, shows excellent microwave dielectric properties of permittivity $\left(\varepsilon_{\mathrm{r}}\right) \approx 93.19$, quality factor $(Q \times f) \approx 9770.14 \mathrm{GHz}$ (at $3.415 \mathrm{GHz})$, and almost near-zero temperature coefficient of resonant frequency $\left(\tau_{f}\right) \approx+4.56 \mathrm{ppm} /{ }^{\circ} \mathrm{C}$.
\end{abstract}

Keywords: tungsten bronze type; high permittivity; microwave dielectric properties

\section{Introduction}

As is well-known, the microwave dielectric ceramic materials with high quality factor $(Q \times f)$ and high permittivity $\left(\varepsilon_{\mathrm{r}}\right)$ have been developed for applications in satellite positioning, navigation, and wireless communication. At present, microwave telecommunication and satellite broadcasting has become one of the fastest developing segments in the communications and electronics industry. Meanwhile, the widespread usage of several wireless systems has required dielectric components that are low-cost, lightweight, small, multifunctional, and highly reliable

\footnotetext{
* Corresponding author.

E-mail: liufeiguet@yahoo.com
}

to reduce the device size. In addition, high dielectric constant, high quality factor, and near-zero temperature coefficient of resonant frequency are three key properties required for microwave resonator materials [1].

In early time, Bolton [2] has reported one unknown $\mathrm{BaO}-\mathrm{Nd}_{2} \mathrm{O}_{3}-\mathrm{TiO}_{2}$ ternary compound, which has a high relative permittivity $\left(\varepsilon_{\mathrm{r}}\right)$ and a low temperature coefficient of resonant frequency $\left(\tau_{f}\right)$. Later, Ohsato and co-workers $[3,4]$ have done extensive work on the preparation, characterization, and structure and property investigation of tungsten bronze type materials. In addition, Valant et al. [5] and Varfolomeeva and Miranov [6] displayed $\mathrm{Ba}_{3.75} \mathrm{Nd}_{9.5} \mathrm{Ti}_{18} \mathrm{O}_{54}$ and $\mathrm{BaNd}_{2} \mathrm{Ti}_{4} \mathrm{O}_{12}$ compounds as specific compositions of the solid solution phase $\mathrm{Ba}_{6-3 x} \mathrm{Nd}_{8+2 x} \mathrm{Ti}_{18} \mathrm{O}_{54}(0 \leqslant$ 
$x \leqslant 0.75)$. According to several authors $[7,8]$, $\mathrm{Ba}_{6-3 x} \mathrm{Ln}_{8+2 x} \mathrm{Ti}_{18} \mathrm{O}_{54}$ ceramics based on $\mathrm{Gd}, \mathrm{Sm}$, and $\mathrm{Nd}$ have high quality factors $(Q \times f)$ up to $14,000 \mathrm{GHz}$, and the La-based ceramics have the highest relative permittivity $\left(\varepsilon_{\mathrm{r}}=104\right)$. Ohsato et al. [9] have also established a relation between the microwave dielectric properties of $\mathrm{Ba}_{6-3 x} \mathrm{Sm}_{8+2 x} \mathrm{Ti}_{18} \mathrm{O}_{54}(0.3 \leqslant x \leqslant 0.7)$ solid solution and the crystal structure. It shows that substitution of $\mathrm{Sm}^{3+}$ for $\mathrm{Ba}^{2+}$ in the large cation sites results in the creation of vacancies and crystal distortion, indicating that the shrinkage of the $\mathrm{TiO}_{6}$ octahedral site plays an important role for the improvement of microwave dielectric properties.

The microwave dielectric properties of $\mathrm{Ba}_{6-3 x} \mathrm{Ln}_{8+2 x}$ $\mathrm{Ti}_{18} \mathrm{O}_{54}(\mathrm{Ln}=\mathrm{La}, \mathrm{Nd}, \mathrm{Sm})$ materials have been studied sufficiently due to their high permittivity. However, the restriction of $Q \times f$ and $\tau_{f}$ values impedes their commercial application [10-13]. Furthermore, there are a large number of active atoms at the solid solution surface, which has a high interfacial dielectric loss induced by interface polarization $[14,15]$. In order to resolve these problems, much work has been done to improve the $Q \times f$ and $\tau_{f}$ values. Many attentions have been paid to improve the microwave dielectric properties by substitution of $\mathrm{Ba}^{2+}$ and $\mathrm{Nd}^{3+}$ ions using $\mathrm{Sr}^{2+}$ and $\mathrm{Y}^{3+}$ ions, as well as adding $\mathrm{NdAlO}_{3}$ or $\mathrm{Al}_{2} \mathrm{O}_{3}$. As can be seen from Table 1, all of them find that the substitution of ions can significantly enhance $Q \times f$ and reduce $\tau_{f}$ [16-19].

$\mathrm{Ba}_{6-3 x} \mathrm{Ln}_{8+2 x} \mathrm{Ti}_{18} \mathrm{O}_{54}(\mathrm{Ln}=\mathrm{La}, \mathrm{Nd}, \mathrm{Sm})$ has been reported to possess high permittivity $\left(\varepsilon_{\mathrm{r}}\right)$ and quality factor $(Q \times f)$ [20-24]. The aim of our present work is to improve the microwave dielectric properties of $\left(\mathrm{Ba}_{1-x} \mathrm{Sr}_{x}\right)_{4}\left(\mathrm{Sm}_{0.4} \mathrm{Nd}_{0.6}\right)_{28 / 3} \mathrm{Ti}_{18} \mathrm{O}_{54}$ by substituting the $\mathrm{Sr}^{2+}$ ions. The effects of substitution of $\mathrm{Sr}^{2+}$ ions on the microstructures and microwave dielectric properties of $\left(\mathrm{Ba}_{1-x} \mathrm{Sr}_{x}\right)_{4}\left(\mathrm{Sm}_{0.4} \mathrm{Nd}_{0.6}\right)_{28 / 3} \mathrm{Ti}_{18} \mathrm{O}_{54} \quad$ ceramics are investigated systematically.

Table 1 Dielectric properties of $\mathrm{Ba}_{6-3 x} \mathrm{Ln}_{8+2 x} \mathrm{Ti}_{18} \mathrm{O}_{54}$ ceramics

\begin{tabular}{lccc}
\hline \multicolumn{1}{c}{ Traditional sample } & $\varepsilon_{\mathrm{r}}$ & $Q \times f(\mathrm{GHz})$ & $\tau_{f}\left(\mathrm{ppm} /{ }^{\circ} \mathrm{C}\right)$ \\
\hline $\mathrm{Ba}_{6-3 x}\left(\mathrm{Sm}_{0.2} \mathrm{Nd}_{0.8}\right)_{8+2 x} \mathrm{Ti}_{18} \mathrm{O}_{54}(x=2 / 3)$ & 80.80 & 8100 & +35.5 \\
$\mathrm{Ba}_{6-3 x}\left(\mathrm{Sm}_{0.9} \mathrm{Bi}_{0.1}\right)_{8+2 x} \mathrm{Ti}_{18} \mathrm{O}_{54}(x=2 / 3)$ & 84.10 & 7840 & -21.0 \\
$\left(\mathrm{Ba}_{1-x} \mathrm{Sr}_{x}\right)_{4.2} \mathrm{Sm}_{9.2} \mathrm{Ti}_{18} \mathrm{O}_{54}(x=0.04)$ & 80.60 & 9590 & -11.9 \\
$\left(\mathrm{Ba}_{0.6} \mathrm{~Pb}_{0.4}\right)_{6-3 x} \mathrm{La}_{8+2 x} \mathrm{Ti}_{18} \mathrm{O}_{54}(x=1.5)$ & 95.00 & 6000 & +200.0 \\
$\mathrm{Ba}_{6-3 x}\left(\mathrm{Sm}_{0.9} \mathrm{La}_{0.1}\right)_{8+2 x} \mathrm{Ti}_{18} \mathrm{O}_{54}(x=2 / 3)$ & 84.00 & 9000 & +4.2 \\
$\left(\mathrm{Ba}_{0.8} \mathrm{Sr}_{0.2}\right)_{6-3 x} \mathrm{Nd}_{8+2 x} \mathrm{Ti}_{18} \mathrm{O}_{54}(x=0.2)$ & 95.00 & 5500 & +125.0 \\
$\left(\mathrm{Ba}_{0.7} \mathrm{Sr}_{0.3}\right)_{4.8}\left(\mathrm{Sm}_{0.7} \mathrm{La}_{0.3}\right)_{8.8} \mathrm{Ti}_{18} \mathrm{O}_{54}$ & 98.77 & 5184 & +10.9 \\
\hline
\end{tabular}

\section{Experimental procedure}

The raw materials were high-purity oxide powders: $\mathrm{BaCO}_{3}$ (99.8\%, Guo-Yao Co. Ltd., Shanghai, China), $\mathrm{SrCO}_{3}$ (99.8\%, Guo-Yao Co. Ltd., Shanghai, China), $\mathrm{Nd}_{2} \mathrm{O}_{3}$ (99.8\%, Guo-Yao Co. Ltd., Shanghai, China), $\mathrm{Sm}_{2} \mathrm{O}_{3}(99.8 \%$, Guo-Yao Co. Ltd., Shanghai, China), and $\mathrm{TiO}_{2}(99 \%$, Guo-Yao Co. Ltd., Shanghai, China), and they were mixed according to the desired stoichiometry $\left(\mathrm{Ba}_{1-x} \mathrm{Sr}_{x}\right)_{4}\left(\mathrm{Sm}_{0.4} \mathrm{Nd}_{0.6}\right)_{28 / 3} \mathrm{Ti}_{18} \mathrm{O}_{54} \quad(x=$ $0.02,0.04,0.06,0.08,0.1)$. The mixed powders were ground in distilled water for $24 \mathrm{~h}$ in a ball mill with $\mathrm{ZrO}_{2}$ balls, then dried and calcined at $1100{ }^{\circ} \mathrm{C}$ for $4 \mathrm{~h}$ in air. The calcined powders were ground into fine powders, and then the fine powders were pressed into pellets with dimensions of $12 \mathrm{~mm}$ in diameter and 5-6 mm in thickness under a pressure of $150 \mathrm{MPa}$, with $5 \mathrm{wt} \%$ PVA as binder. These pellets were sintered at temperatures of $1400-1460{ }^{\circ} \mathrm{C}$ for $4 \mathrm{~h}$ in air.

The apparent density $\left(\rho_{\mathrm{a}}\right)$ of sintered ceramics was measured by the Archimedes method, and the bulk density $\left(\rho_{\mathrm{b}}\right)$ was evaluated from the dimensions and weight. Correspondingly, the relative density $\left(\rho_{\mathrm{r}}\right)$ was calculated with the following formula:

$$
\rho_{\mathrm{r}}=\frac{\rho_{\mathrm{a}}}{\rho_{\mathrm{b}}} \times 100 \%
$$

The crystalline phases of the sintered ceramics were identified by X-ray diffraction (XRD) using $\mathrm{Cu} \mathrm{Ka}$ radiation (Rigaku D/MAX-2400 X-ray diffractometer, Tokyo, Japan). Surface topologies of the ceramics were observed by scanning electron microscopy (SEM; JSM-6460, JEOL, Tokyo, Japan). Meanwhile, in order to investigate the effect of $\mathrm{Sr}^{2+}$ substitution for $\mathrm{Ba}^{2+}$, the $\quad\left(\mathrm{Ba}_{1-x} \mathrm{Sr}_{x}\right)_{4}\left(\mathrm{Sm}_{0.4} \mathrm{Nd}_{0.6}\right)_{28 / 3} \mathrm{Ti}_{18} \mathrm{O}_{54} \quad(x=0.08)$ ceramic was studied by energy-dispersive $\mathrm{X}$-ray spectroscopy (EDX). Microwave dielectric properties of the ceramics were measured by the $\mathrm{TE}_{01 \delta}$ shielded cavity method with a network analyzer (8720ES, Agilent, Palo Alto, CA, USA) and a temperature chamber (Delta9023, Delta Design, Poway, CA, USA) in the temperature range of $25-75{ }^{\circ} \mathrm{C}[25,26]$. The temperature coefficient of resonant frequency $\left(\tau_{f}\right)$ value was calculated with the following formula [27]:

$$
\tau_{f}=\frac{\Delta f_{0}}{f_{0} \Delta T}=\frac{f_{75}-f_{25}}{f_{25} \times 50}
$$

where $f_{25}$ and $f_{75}$ were the resonant frequencies at $25^{\circ} \mathrm{C}$ and $75^{\circ} \mathrm{C}$, respectively. 


\section{Results and discussion}

\section{1 Crystalline structures}

Figure 1(a) illustrates the room-temperature XRD patterns recorded from $\left(\mathrm{Ba}_{1-x} \mathrm{Sr}_{x}\right)_{4}\left(\mathrm{Sm}_{0.4} \mathrm{Nd}_{0.6}\right)_{28 / 3}$ $\mathrm{Ti}_{18} \mathrm{O}_{54}(x=0.02,0.04,0.06,0.08,0.1)$ ceramics sintered at $1440{ }^{\circ} \mathrm{C}$ for $4 \mathrm{~h}$. As shown in Fig. 1(a), Bragg peaks corresponding to the tungsten bronze-like crystal structure are observed in the ceramics. And it can be indexed as a tungsten bronze structure with formulae $\mathrm{BaSm}_{2} \mathrm{Ti}_{4} \mathrm{O}_{12}$ (JCPDS Card No. 44-0062) and $\mathrm{BaNd}_{2} \mathrm{Ti}_{5} \mathrm{O}_{14}$ (JCPDS Card No. 33-0166), belonging to orthorhombic phase. All the samples doped with different amounts of $\mathrm{Sr}^{2+}$ ions have the same diffraction patterns. In the $\mathrm{Ba}(\mathrm{A} 2) \mathrm{Nd}_{2}(\mathrm{~A} 1) \mathrm{Ti}_{5}(\mathrm{~B}) \mathrm{O}_{14}$ solid solution, there are three kinds of cations with different ionic radii in the crystal structure. The middle-sized $\mathrm{Ln}^{3+}$ ions
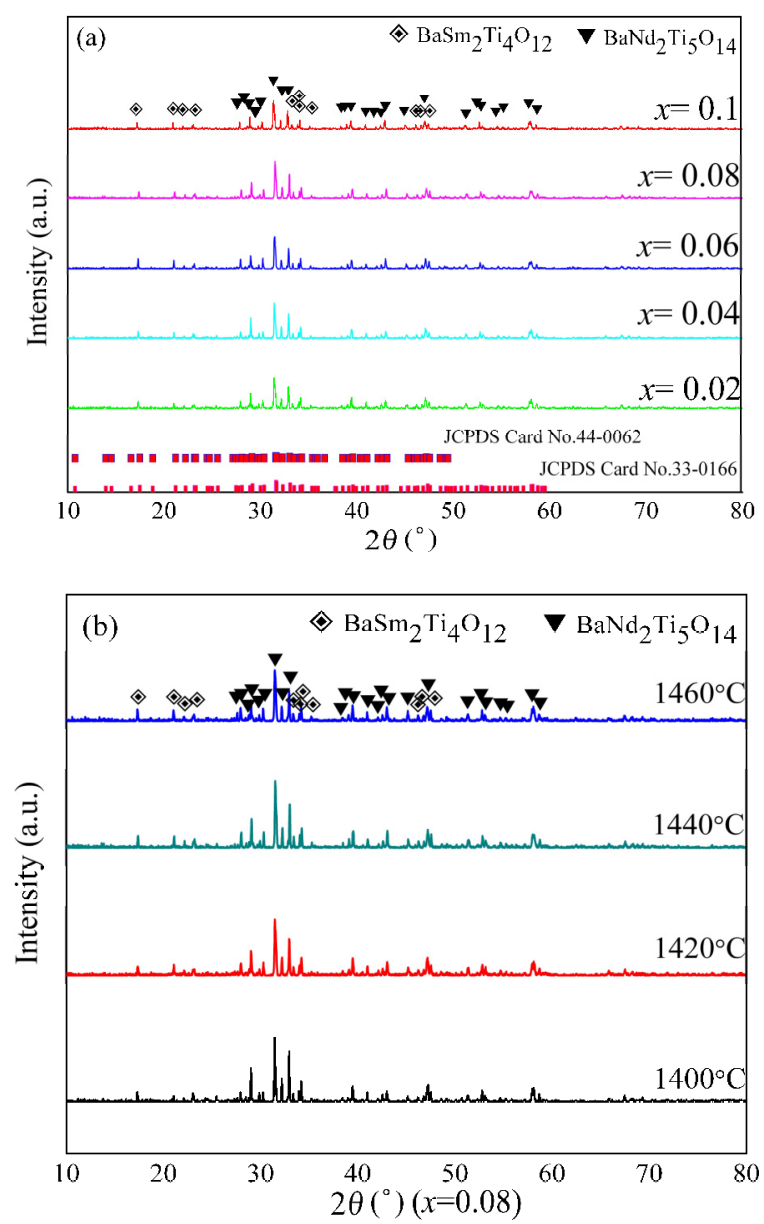

Fig. 1 XRD patterns of $\left(\mathrm{Ba}_{1-x} \mathrm{Sr}_{x}\right)_{4}\left(\mathrm{Sm}_{0.4} \mathrm{Nd}_{0.6}\right)_{28 / 3} \mathrm{Ti}_{18} \mathrm{O}_{54}$ ceramic specimens: (a) $\left(\mathrm{Ba}_{1-x} \mathrm{Sr}_{x}\right)_{4}\left(\mathrm{Sm}_{0.4} \mathrm{Nd}_{0.6}\right)_{28 / 3} \mathrm{Ti}_{18} \mathrm{O}_{54}$ $(x=0.02,0.04,0.06,0.08,0.1)$ ceramics sintered at $1440{ }^{\circ} \mathrm{C}$ for $4 \mathrm{~h}$; (b) $\left(\mathrm{Ba}_{1-x} \mathrm{Sr}_{x}\right)_{4}\left(\mathrm{Sm}_{0.4} \mathrm{Nd}_{0.6}\right)_{28 / 3} \mathrm{Ti}_{18} \mathrm{O}_{54}(x=0.08)$ ceramic at different sintering temperatures. mainly occupy $\mathrm{A} 1$ rhombic sites, the largest $\mathrm{Ba}^{2+}$ ions mainly occupy pentagonal A2 sites, and the smallest $\mathrm{Ti}^{4+}$ ions alone occupy octahedral B sites [28]. The A2 sites are occupied by four $\mathrm{Ba}^{2+}$ ions and $\mathrm{A} 1$ sites by eight $\mathrm{Ln}^{3+}$ ions. Therefore, the dielectric properties of the solid solutions are highly influenced by crystal structure. Substitution of $\mathrm{Sr}^{2+}$ ions $\left(1.44 \AA\right.$ ) for $\mathrm{Ba}^{2+}$ ions $(1.61 \AA)$ in the large cation sites (A2) results in the crystal distortion, showing that the shrinkage of the $\mathrm{TiO}_{6}$ octahedral site plays an important role for improvement of the microwave dielectric properties. At the same time, the distortion of the crystal lattice of the $\mathrm{BaNd}_{2} \mathrm{Ti}_{5} \mathrm{O}_{14}$ phase is also expected to influence the microwave dielectric properties of the produced ceramics, which is attributed to the presence of $\mathrm{Sr}^{2+}$ ions substituted for $\mathrm{Ba}^{2+}$ cations. As can be seen from Fig. 1(b), with increasing sintering temperature, $\mathrm{BaNd}_{2} \mathrm{Ti}_{5} \mathrm{O}_{14}$ and $\mathrm{BaSm}_{2} \mathrm{Ti}_{4} \mathrm{O}_{12}$ diffraction peaks are not obviously changed, and $\mathrm{BaNd}_{2} \mathrm{Ti}_{5} \mathrm{O}_{14}$ diffraction peaks at the angles of $38^{\circ}-40^{\circ}$ are strengthened for the specimen sintered at $1440{ }^{\circ} \mathrm{C}$.

\section{2 Microstructures and density}

Figure 2 shows the SEM micrographs of $\left(\mathrm{Ba}_{1-x} \mathrm{Sr}_{x}\right)_{4}\left(\mathrm{Sm}_{0.4} \mathrm{Nd}_{0.6}\right)_{28 / 3} \mathrm{Ti}_{18} \mathrm{O}_{54}$ ceramics sintered at $1440{ }^{\circ} \mathrm{C}$ for $4 \mathrm{~h}$. As can be found from the micrographs, all the samples show dense and homogeneous microstructures. Also, with the increase in the number of $\mathrm{Sr}^{2+}$ ions, the pores appear in the microstructures. At the same time, an excess of $\mathrm{Sr}^{2+}$ ions results in the agglomeration phenomena, preventing the better densification. On the other hand, EDX analysis was used by combining with SEM to prove that the substitution of $\mathrm{Sr}^{2+}$ for $\mathrm{Ba}^{2+}$ has been successfully executed, as shown in Fig. 3. It is obvious that the $\mathrm{Sr}^{2+}$ ions can substitute for $\mathrm{Ba}^{2+}$ ions, which is in agreement with the results of XRD patterns in Fig. 1(a). In addition, in order to understand how the $\mathrm{Sr}^{2+}$ ions affect the microstructures of $\left(\mathrm{Ba}_{1-x} \mathrm{Sr}_{x}\right)_{4}\left(\mathrm{Sm}_{0.4} \mathrm{Nd}_{0.6}\right)_{28 / 3}$ $\mathrm{Ti}_{18} \mathrm{O}_{54} \quad(0.02 \leqslant x \leqslant 0.1) \quad$ ceramics, cross-sectional SEM micrographs are taken as shown in Fig. 4. $\left(\mathrm{Ba}_{1-x} \mathrm{Sr}_{x}\right)_{4}\left(\mathrm{Sm}_{0.4} \mathrm{Nd}_{0.6}\right)_{28 / 3} \mathrm{Ti}_{18} \mathrm{O}_{54} \quad(0.02 \leqslant x \leqslant 0.1)$ ceramics show agglomeration and dense and homogeneous microstructures. Furthermore, it can be clearly seen that the porosity increases with increasing $x$ value, implying that an increase of $\mathrm{Sr}^{2+}$ ions $(x \geqslant 0.1)$ may deteriorate the densification of the specimens. From the observation of microstructure, the $Q \times f$ value is influenced by the defect, which results from that the 

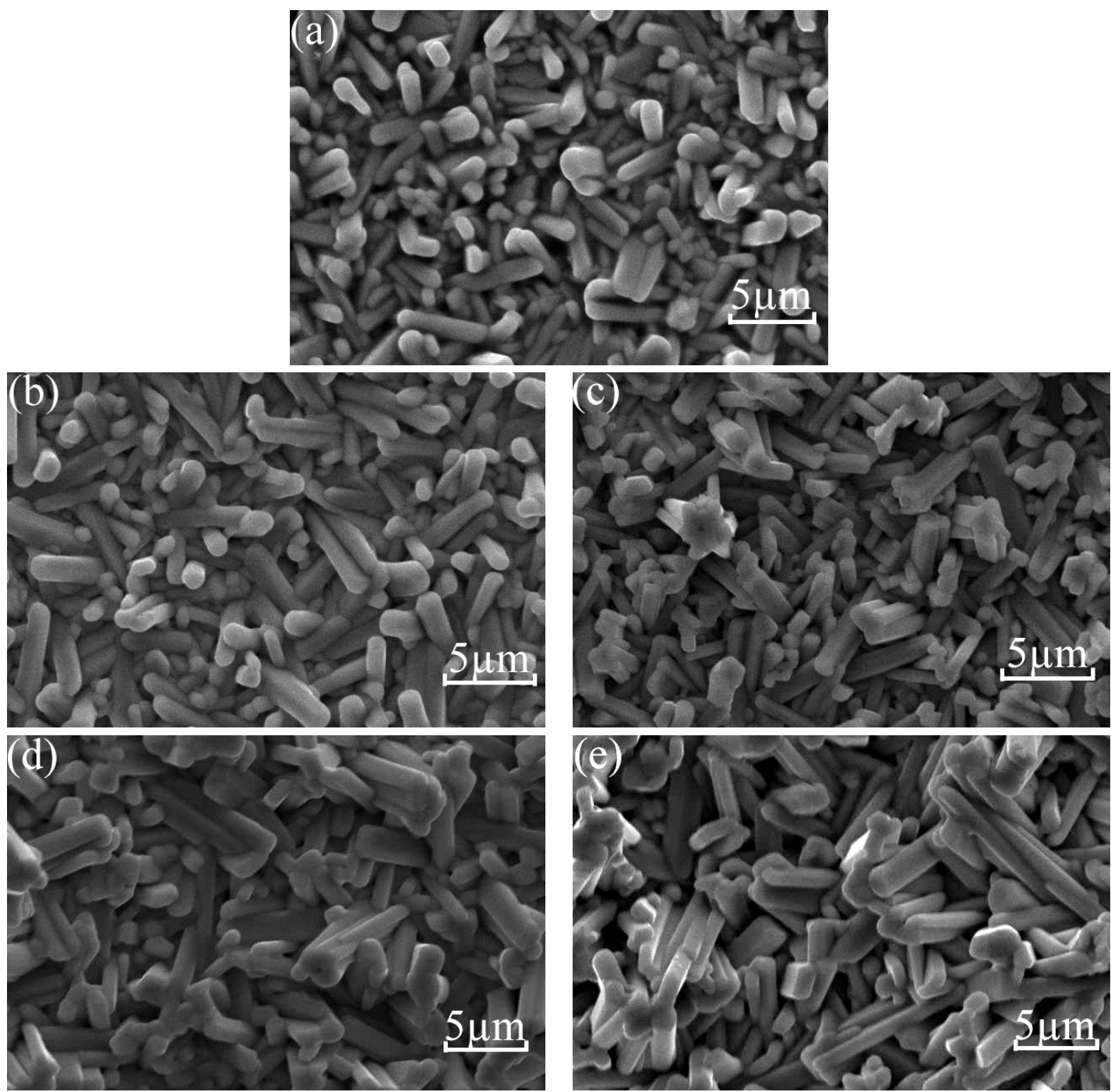

Fig. 2 SEM micrographs of $\left(\mathrm{Ba}_{1-x} \mathrm{Sr}_{x}\right)_{4}\left(\mathrm{Sm}_{0.4} \mathrm{Nd}_{0.6}\right)_{28 / 3} \mathrm{Ti}_{18} \mathrm{O}_{54}$ ceramics with (a) $x=0.02$, (b) $x=0.04$, (c) $x=0.06$, (d) $x=0.08$, and (e) $x=0.1$, sintered at $1440{ }^{\circ} \mathrm{C}$ for $4 \mathrm{~h}$.
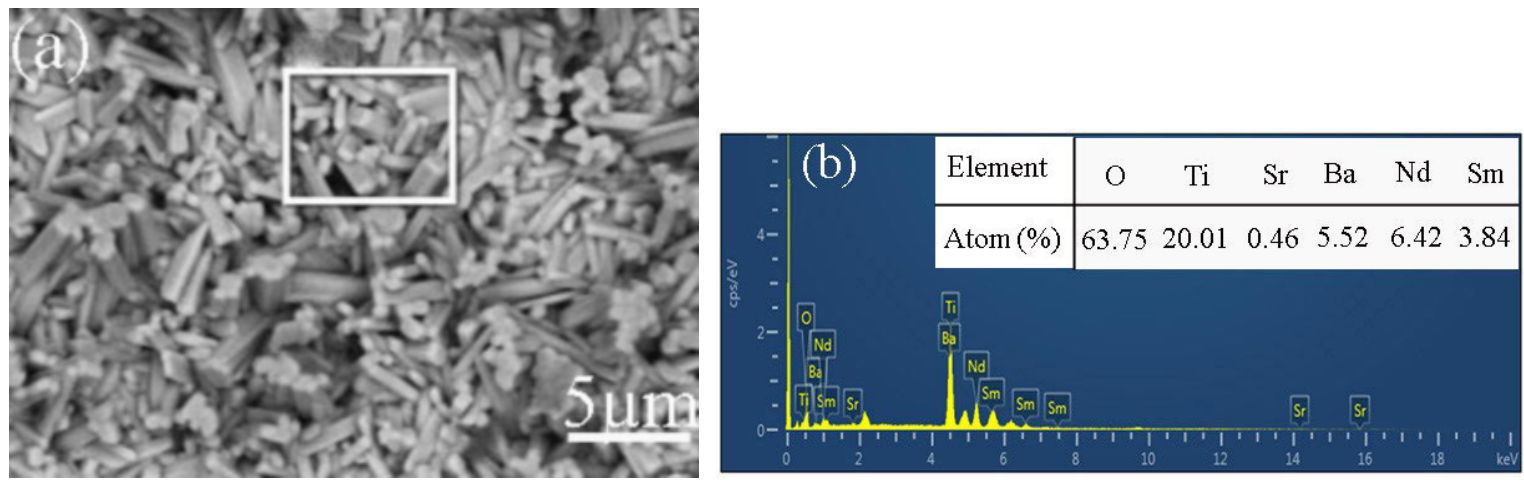

Fig. 3 EDX analysis of the $\left(\mathrm{Ba}_{1-x} \mathrm{Sr}_{x}\right)_{4}\left(\mathrm{Sm}_{0.4} \mathrm{Nd}_{0.6}\right)_{28 / 3} \mathrm{Ti}_{18} \mathrm{O}_{54}$ ceramic $(x=0.08)$ sintered at $1440{ }^{\circ} \mathrm{C}$ for $4 \mathrm{~h}$.

defect can reduce the compactness of sintered ceramics and cause a decrease in $Q \times f$ value. In addition, Fig. 5 shows the SEM images of the $\left(\mathrm{Ba}_{1-x} \mathrm{Sr}_{x}\right)_{4}$ $\left(\mathrm{Sm}_{0.4} \mathrm{Nd}_{0.6}\right)_{28 / 3} \mathrm{Ti}_{18} \mathrm{O}_{54}$ ceramic with $x=0.08$ sintered at different temperatures. As seen in Fig. 5, for the composition with $x=0.08$, the densification degree increases with the increasing sintering temperature from 1400 to $1440{ }^{\circ} \mathrm{C}$, and then decreases gradually when the sintering temperature is raised around $1460{ }^{\circ} \mathrm{C}$. This phenomenon means that the degree of 

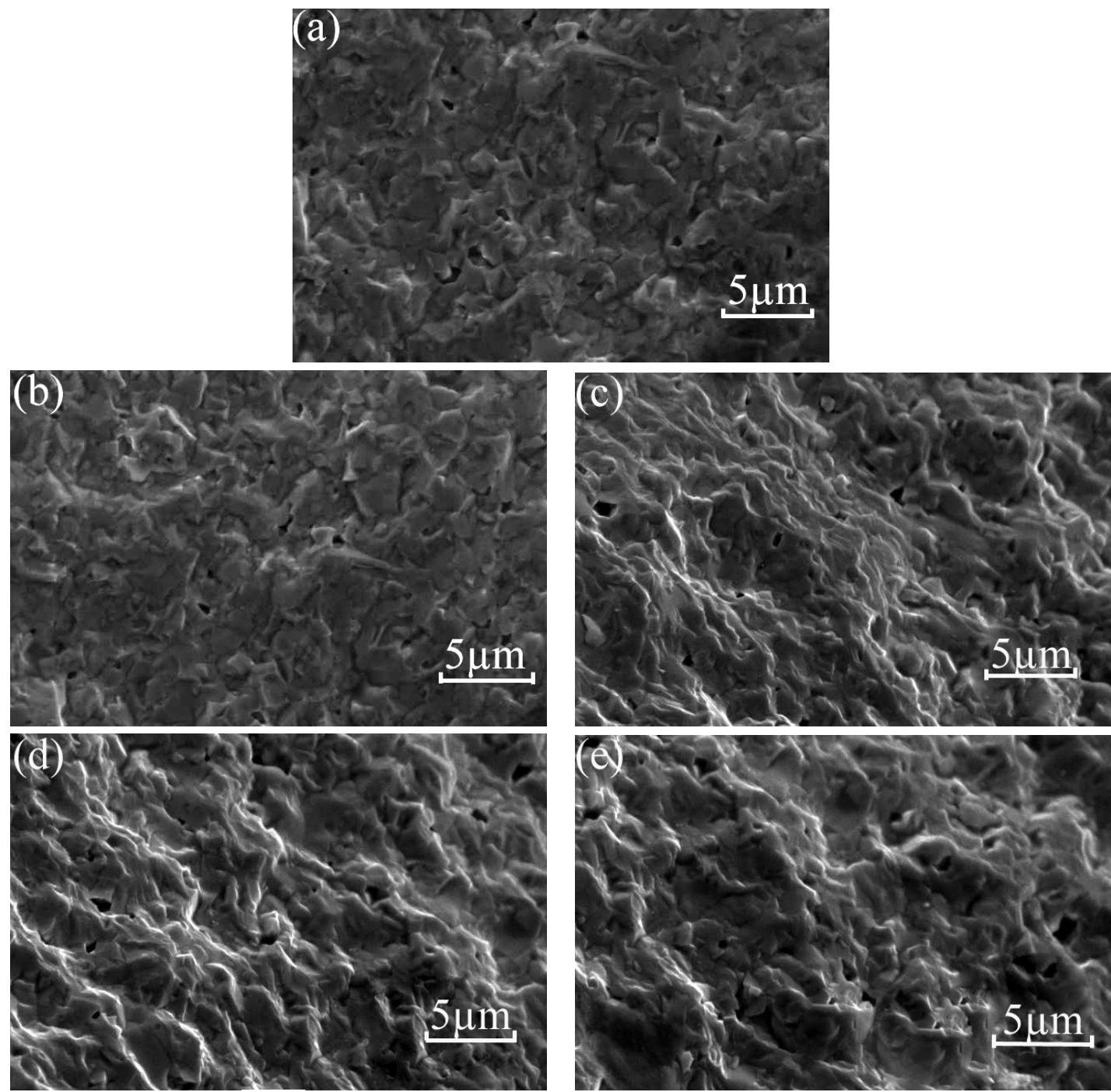

Fig. 4 SEM micrographs of the cross-section of $\left(\mathrm{Ba}_{1-x} \mathrm{Sr}_{x}\right)_{4}\left(\mathrm{Sm}_{0.4} \mathrm{Nd}_{0.6}\right)_{28 / 3} \mathrm{Ti}_{18} \mathrm{O}_{54}$ ceramics with (a) $x=0.02$, (b) $x=0.04$, (c) $x=0.06$, (d) $x=0.08$, and (e) $x=0.1$, sintered at $1440{ }^{\circ} \mathrm{C}$ for $4 \mathrm{~h}$.

densification at $1440{ }^{\circ} \mathrm{C}$ is higher than that of other sintering temperatures.

In addition, Fig. 6(a) shows the apparent density and relative density of the $\left(\mathrm{Ba}_{1-x} \mathrm{Sr}_{x}\right)_{4}\left(\mathrm{Sm}_{0.4} \mathrm{Nd}_{0.6}\right)_{28 / 3} \mathrm{Ti}_{18} \mathrm{O}_{54} \quad(0.02 \leqslant x \leqslant 0.1)$ ceramics. As can be seen from Fig. 6(a), the increasing $\mathrm{Sr}^{2+}$ content causes a reduction of the apparent density of the ceramics. At the same time, from Fig. $6(\mathrm{~b})$, it is found that apparent density and relative density of the $\left(\mathrm{Ba}_{1-x} \mathrm{Sr}_{x}\right)_{4}\left(\mathrm{Sm}_{0.4} \mathrm{Nd}_{0.6}\right)_{28 / 3} \mathrm{Ti}_{18} \mathrm{O}_{54}$ $(x=0.08)$ ceramic gradually increase with the increase of sintering temperature and then obviously decrease at the further sintering temperature. Furthermore, the apparent density of $\left(\mathrm{Ba}_{1-x} \mathrm{Sr}_{x}\right)_{4}\left(\mathrm{Sm}_{0.4} \mathrm{Nd}_{0.6}\right)_{28 / 3} \mathrm{Ti}_{18} \mathrm{O}_{54}$ $(x=0.08)$ ceramic reaches the maximum value at $1440{ }^{\circ} \mathrm{C}$ for $4 \mathrm{~h}$. The larger apparent density means the less crystal imperfection and porosity in the sample's interior structure, and a higher $Q \times f$ value will be obtained.

\section{3 Dielectric properties}

Figure 7(a) shows the variation of the $Q \times f$ value and permittivity $\left(\varepsilon_{\mathrm{r}}\right)$ of $\left(\mathrm{Ba}_{1-x} \mathrm{Sr}_{x}\right)_{4}\left(\mathrm{Sm}_{0.4} \mathrm{Nd}_{0.6}\right)_{28 / 3} \mathrm{Ti}_{18} \mathrm{O}_{54}$ ceramics sintered at $1400{ }^{\circ} \mathrm{C}$ for $4 \mathrm{~h}$. According to the literature [29], the $Q \times f$ value and permittivity $\left(\varepsilon_{\mathrm{r}}\right)$ of $\mathrm{Ba}_{6-3 y}\left(\mathrm{Sm}_{0.4} \mathrm{Nd}_{0.6}\right)_{8+2 y} \mathrm{Ti}_{18} \mathrm{O}_{54} \quad(y=2 / 3)$ ceramic is $\sim 10,700 \mathrm{GHz}$ and $\sim 82.7$, respectively. As shown in Fig. 7(a), after adding $\mathrm{Sr}^{2+}$ ions into the system, the permittivity $\left(\varepsilon_{\mathrm{r}}\right)$ firstly increases from 90.82 to 93.19 while $x$ value varies from 0.02 to 0.08 , and then the permittivity $\left(\varepsilon_{\mathrm{r}}\right)$ decreases to 89.76 at $x=0.1$. This improvement may be caused by the relaxation of local 

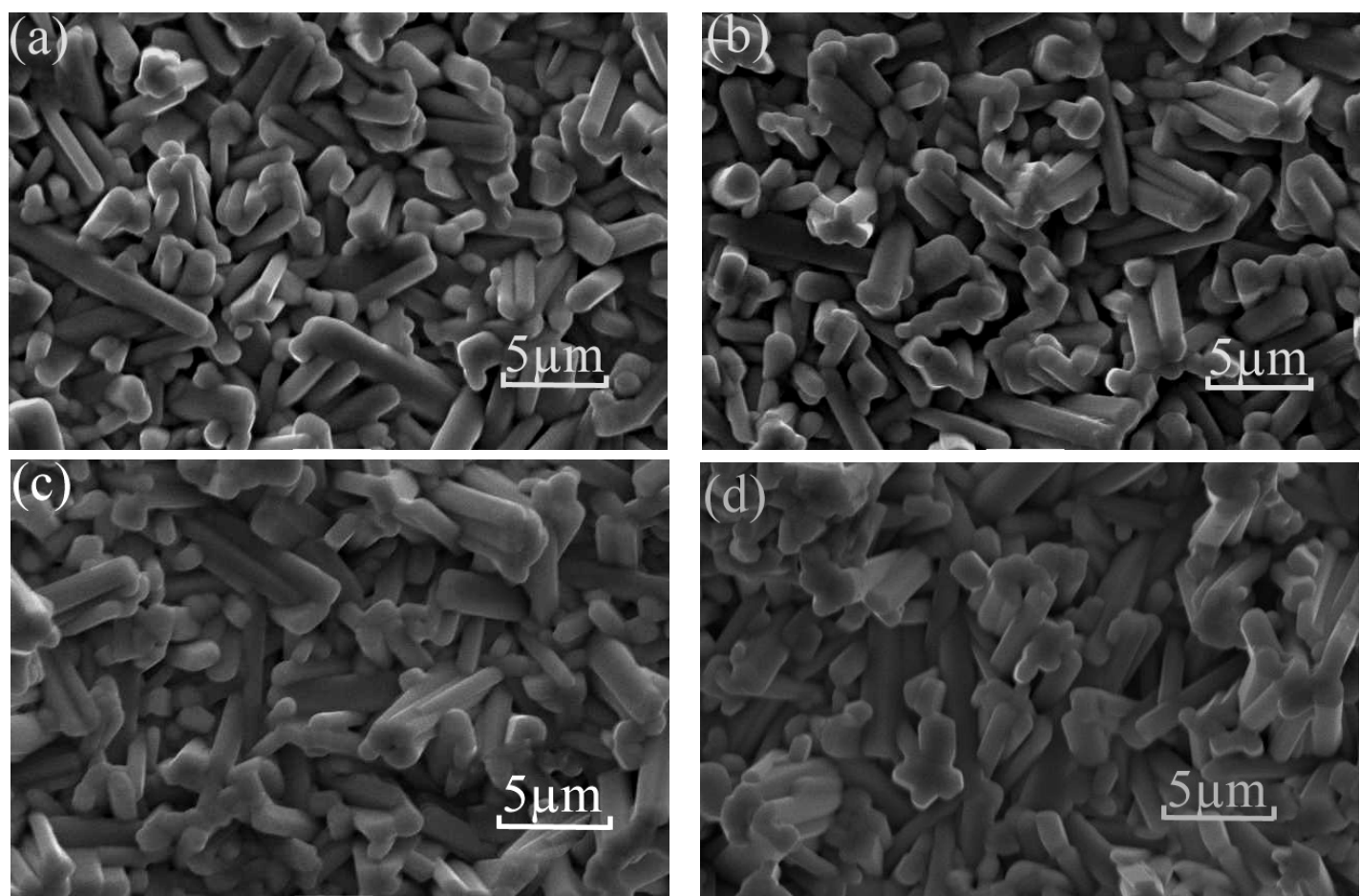

Fig. 5 SEM micrographs of $\left(\mathrm{Ba}_{1-x} \mathrm{Sr}_{x}\right)_{4}\left(\mathrm{Sm}_{0.4} \mathrm{Nd}_{0.6}\right)_{28 / 3} \mathrm{Ti}_{18} \mathrm{O}_{54}$ ceramic for $x=0.08$ sintered at various temperatures with (a) $1400{ }^{\circ} \mathrm{C}$, (b) $1420{ }^{\circ} \mathrm{C}$, (c) $1440{ }^{\circ} \mathrm{C}$, (d) $1460{ }^{\circ} \mathrm{C}$.
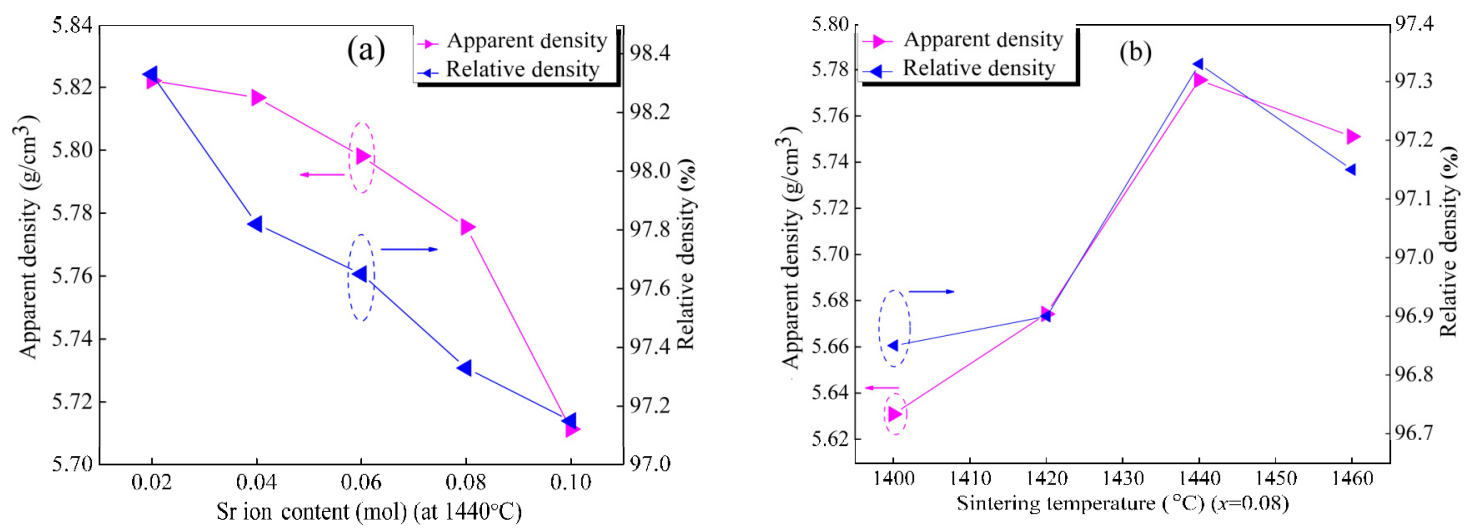

Fig. 6 (a) Influence of the apparent density and relative density of the $\left(\mathrm{Ba}_{1-x} \mathrm{Sr}_{x}\right)_{4}\left(\mathrm{Sm}_{0.4} \mathrm{Nd}_{0.6}\right)_{28 / 3} \mathrm{Ti}_{18} \mathrm{O}_{54}$ ceramics on the amount of $\mathrm{Sr}^{2+}$ ions; (b) influence of the apparent density and relative density of the $\left(\mathrm{Ba}_{1-x} \mathrm{Sr}_{x}\right)_{4}\left(\mathrm{Sm}_{0.4} \mathrm{Nd}_{0.6}\right)_{28 / 3} \mathrm{Ti}_{18} \mathrm{O}_{54}(x=0.08)$ ceramic at different sintering temperatures.

distortions at A2 sites, which results from the substitution of smaller $\mathrm{Sr}^{2+}$ ions for $\mathrm{Ba}^{2+}$ ions [30]. Meanwhile, the corresponding $Q \times f$ value slightly decreases from 10264 to $9200 \mathrm{GHz}$ while $x$ varies from 0.02 to 0.1 . The dielectric relaxation caused by its large resistivity is one of the reason for the dielectric loss of $\left(\mathrm{Ba}_{1-x} \mathrm{Sr}_{x}\right)_{4}\left(\mathrm{Sm}_{0.4} \mathrm{Nd}_{0.6}\right)_{28 / 3} \mathrm{Ti}_{18} \mathrm{O}_{54}$ ceramics [31-33]. Herein, the optimal microwave dielectric properties of $\varepsilon_{\mathrm{r}} \approx 93.19, Q \times f \approx 9770.14 \mathrm{GHz}$ (at $3.415 \mathrm{GHz}$ ) can be achieved at $x=0.08$. The uprising of permittivity $\left(\varepsilon_{\mathrm{r}}\right)$ with $x$ value should be attributed to the presence of $\mathrm{Sr}^{2+}$ ions substituted for $\mathrm{Ba}^{2+}$ ions and the coexistence of
$\mathrm{BaSm}_{2} \mathrm{Ti}_{4} \mathrm{O}_{12}$ and $\mathrm{BaNd}_{2} \mathrm{Ti}_{5} \mathrm{O}_{14}$ phases. In addition, the $Q \times f$ value and $\varepsilon_{\mathrm{r}}$ of the $\left(\mathrm{Ba}_{1-x} \mathrm{Sr}_{x}\right)_{4}\left(\mathrm{Sm}_{0.4} \mathrm{Nd}_{0.6}\right)_{28 / 3}$ $\mathrm{Ti}_{18} \mathrm{O}_{54}$ ceramic for $x=0.08$ as a function of its sintering temperature for $4 \mathrm{~h}$ are shown in Fig. 7(b). In Fig. 7(b), the $Q \times f$ value of the $\left(\mathrm{Ba}_{1-x} \mathrm{Sr}_{x}\right)_{4}$ $\left(\mathrm{Sm}_{0.4} \mathrm{Nd}_{0.6}\right)_{28 / 3} \mathrm{Ti}_{18} \mathrm{O}_{54}$ ceramic for $x=0.08$ sintered at $1440{ }^{\circ} \mathrm{C}$ is relatively high due to the high density and the compact microstructure. With an increasing of sintering temperature, the $Q \times f$ value of the $\left(\mathrm{Ba}_{1-x} \mathrm{Sr}_{x}\right)_{4}\left(\mathrm{Sm}_{0.4} \mathrm{Nd}_{0.6}\right)_{28 / 3} \mathrm{Ti}_{18} \mathrm{O}_{54}$ ceramic for $x=0.08$ increases to a maximum value of $9770.14 \mathrm{GHz}$ (at $3.415 \mathrm{GHz}$ ) and decreases thereafter. 

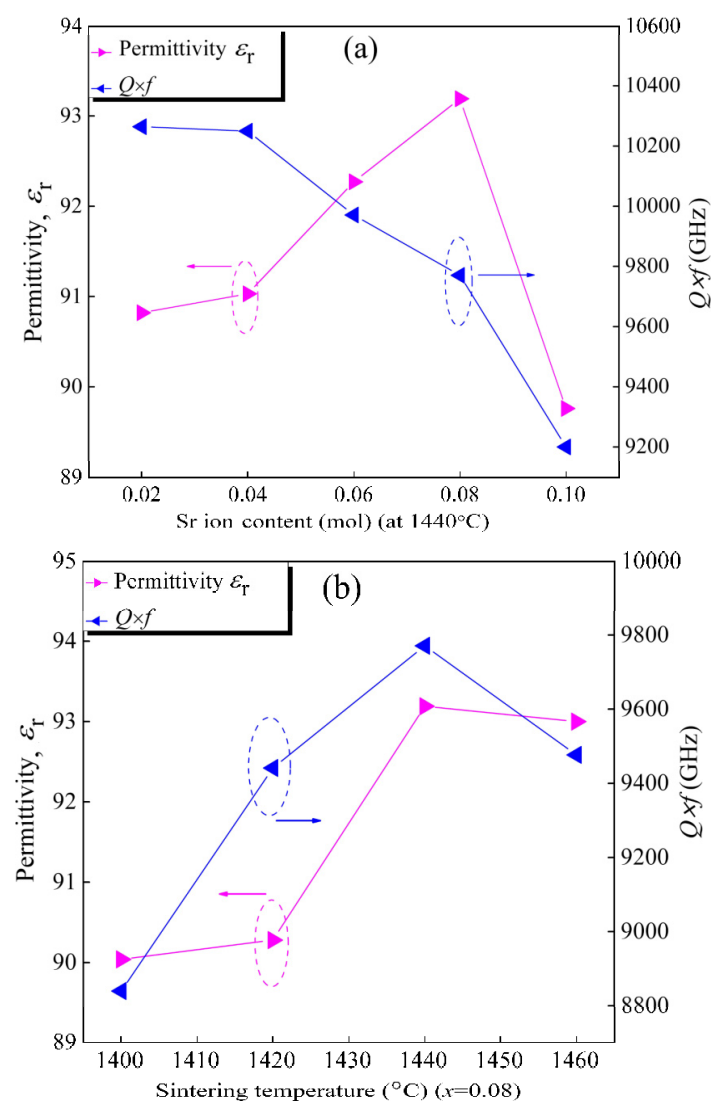

Fig. 7 (a) Influence of the $Q \times f$ value and dielectric constant $\left(\varepsilon_{\mathrm{r}}\right)$ of the $\left(\mathrm{Ba}_{1-x} \mathrm{Sr}_{x}\right)_{4}\left(\mathrm{Sm}_{0.4} \mathrm{Nd}_{0.6}\right)_{28 / 3} \mathrm{Ti}_{18} \mathrm{O}_{54}$ ceramics on the amount of $\mathrm{Sr}^{2+}$ ions; (b) influence of the $Q \times f$ value and dielectric constant $\left(\varepsilon_{\mathrm{r}}\right)$ of the $\left(\mathrm{Ba}_{1-x} \mathrm{Sr}_{x}\right)_{4}\left(\mathrm{Sm}_{0.4} \mathrm{Nd}_{0.6}\right)_{28 / 3} \mathrm{Ti}_{18} \mathrm{O}_{54} \quad(x=0.08)$ ceramic at different sintering temperatures.

Figure 8 shows the variation of $\tau_{f}$, electronegativity (e), and tolerance factor $(t)$ of the $\left(\mathrm{Ba}_{1-x} \mathrm{Sr}_{x}\right)_{4}\left(\mathrm{Sm}_{0.4} \mathrm{Nd}_{0.6}\right)_{28 / 3} \mathrm{Ti}_{18} \mathrm{O}_{54} \quad(0.02 \leqslant x \leqslant 0.1)$ ceramics sintered at $1440{ }^{\circ} \mathrm{C}$ for 4 h. In Fig. 8 , it is noted that the changes of $\tau_{f}$, electronegativity $(e)$, and tolerance factor $(t)$ show the same trend with the increase of $x$ value, and the minimum values of all the parameters can be obtained at $x=0.1$, which indicates that the changes of $\tau_{f}$ are mainly dependent on the electronegativity $(e)$ and tolerance factor $(t)$ of the $\left(\mathrm{Ba}_{1-x} \mathrm{Sr}_{x}\right)_{4}\left(\mathrm{Sm}_{0.4} \mathrm{Nd}_{0.6}\right)_{28 / 3} \mathrm{Ti}_{18} \mathrm{O}_{54}$ ceramics. Therefore, the value of $\tau_{f}$ can be adjusted by $\mathrm{Sr}^{2+}$ ion addition with changing in the tolerance factor $(t)$. Wherein, the tolerance factor can be calculated by the following equation:

$$
t=\frac{\frac{14}{15}\left(0.4 R_{\mathrm{Sm}^{3+}}+0.6 R_{\mathrm{Nd}^{3+}}\right)+\frac{1}{15}\left[(1-x) R_{\mathrm{Ba}^{2+}}+x R_{\mathrm{Sr}^{2+}}\right]+R_{\mathrm{O}^{2-}}}{\sqrt{2}\left(R_{\mathrm{Ti}^{4+}}+R_{\mathrm{O}^{2-}}\right)}
$$

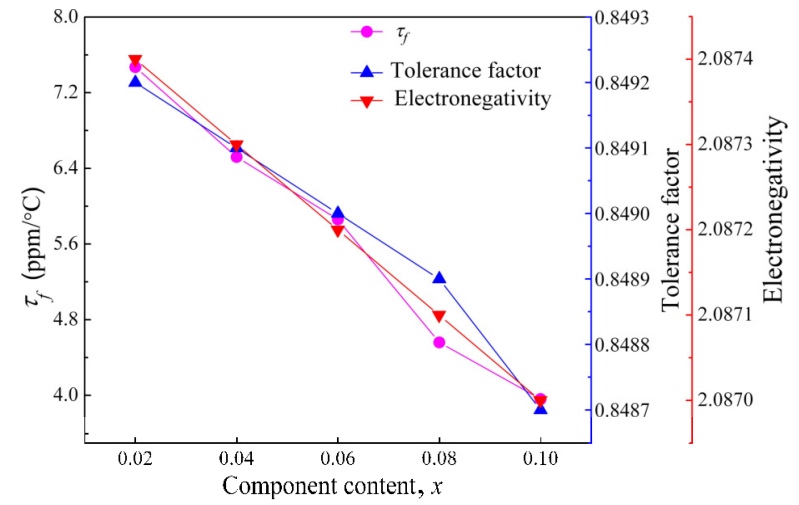

Fig. 8 Variation of the temperature coefficient of resonant frequency $\left(\tau_{f}\right)$, electronegativity $(e)$, and tolerance factor (t) of the $\left(\mathrm{Ba}_{1-x} \mathrm{Sr}_{x}\right)_{4}\left(\mathrm{Sm}_{0.4} \mathrm{Nd}_{0.6}\right)_{28 / 3} \mathrm{Ti}_{18} \mathrm{O}_{54}$ ceramics with different $x$ values sintered at $1440{ }^{\circ} \mathrm{C}$ for $4 \mathrm{~h}$.

where $R_{\mathrm{Sm}^{3+}}, R_{\mathrm{Nd}^{3+}}, R_{\mathrm{Ba}^{2+}}, R_{\mathrm{Sr}^{2+}}, R_{\mathrm{Ti}^{4+}}$, and $R_{\mathrm{O}^{2-}}$ represent the ionic radii of $\mathrm{Sm}^{3+}, \mathrm{Nd}^{3+}, \mathrm{Ba}^{2+}, \mathrm{Sr}^{2+}, \mathrm{Ti}^{\mathrm{O}^{2+}}$, and $\mathrm{O}^{2-}$, respectively [34,35]. In addition, the reduction of $t$ illustrates that the symmetry in $\mathrm{BaNd}_{2} \mathrm{Ti}_{5} \mathrm{O}_{14}$ phase has a reduction in the increase of $x$ value. With the increase of the $\mathrm{Sr}^{2+}$ ion content, the electronegativity of the tungsten bronze structure almost decreases linearly. Meanwhile, the changes of $\tau_{f}$ are almost consistent with the variation of electronegativity, which also shows that the $\tau_{f}$ values are strongly related with the electronegativity in tungsten bronze structure. Wherein, the electronegativity $(e)$ of the $\left(\mathrm{Ba}_{1-x} \mathrm{Sr}_{x}\right)_{4}$ $\left(\mathrm{Sm}_{0.4} \mathrm{Nd}_{0.6}\right)_{28 / 3} \mathrm{Ti}_{18} \mathrm{O}_{54}$ solid solution can be calculated by the following equation:

$$
e=\frac{4\left[(1-x) X_{\mathrm{Ba}-\mathrm{O}}+x X_{\mathrm{S}-\mathrm{O}}\right]+\frac{28}{3}\left(0.4 X_{\mathrm{Sm}-\mathrm{O}}+0.6 X_{\mathrm{Nd}-\mathrm{O}}\right)+18 X_{\mathrm{Ti}-\mathrm{O}}}{32-\frac{2}{3}}
$$

where $X_{\mathrm{Ba}-\mathrm{O}}, X_{\mathrm{Sr}-\mathrm{O}}, X_{\mathrm{Sm}-\mathrm{O}}, X_{\mathrm{Nd}-\mathrm{O}}$, and $X_{\mathrm{Ti}-\mathrm{O}}$ represent the electronegativity difference of $\mathrm{Ba}^{2+}, \mathrm{Sr}^{2+}$, $\mathrm{Sm}^{3+}, \mathrm{Nd}^{3+}$, and $\mathrm{Ti}^{4+}$ with $\mathrm{O}^{2-}$, respectively [36].

\section{Conclusions}

$\left(\mathrm{Ba}_{1-x} \mathrm{Sr}_{x}\right)_{4}\left(\mathrm{Sm}_{0.4} \mathrm{Nd}_{0.6}\right)_{28 / 3} \mathrm{Ti}_{18} \mathrm{O}_{54}(x=0.02,0.04,0.06$, $0.08,0.1)$ ceramics were prepared by the conventional solid-state reaction method and well densified at $\sim 1440{ }^{\circ} \mathrm{C}$. The phase structures, grain morphologies, and microwave dielectric properties of the $\left(\mathrm{Ba}_{1-x} \mathrm{Sr}_{x}\right)_{4}$ $\left(\mathrm{Sm}_{0.4} \mathrm{Nd}_{0.6}\right)_{28 / 3} \mathrm{Ti}_{18} \mathrm{O}_{54}$ ceramics were studied. The phase structures and microwave dielectric properties were greatly influenced by $x$ value. The optimal 
microwave dielectric properties with a permittivity $\left(\varepsilon_{\mathrm{r}}\right) \approx 93.19$, a quality factor $(Q \times f) \approx 9770.14 \mathrm{GHz}$ (at $3.415 \mathrm{GHz}$ ), and an almost near-zero temperature coefficient of resonant frequency $\left(\tau_{f}\right) \approx+4.56 \mathrm{ppm} /{ }^{\circ} \mathrm{C}$ can be obtained for the $\left(\mathrm{Ba}_{0.92} \mathrm{Sr}_{0.08}\right)_{4}\left(\mathrm{Sm}_{0.4} \mathrm{Nd}_{0.6}\right)_{28 / 3}$ $\mathrm{Ti}_{18} \mathrm{O}_{54}$ specimen sintered at $1440{ }^{\circ} \mathrm{C}$ for $4 \mathrm{~h}$. Also, these results indicated that the $\left(\mathrm{Ba}_{0.92} \mathrm{Sr}_{0.08}\right)_{4}$ $\left(\mathrm{Sm}_{0.4} \mathrm{Nd}_{0.6}\right)_{28 / 3} \mathrm{Ti}_{18} \mathrm{O}_{54}$ ceramic with very high permittivity $\left(\varepsilon_{\mathrm{r}}\right)$, high quality factor $(Q \times f)$, and almost near-zero temperature coefficient of resonant frequency $\left(\tau_{f}\right)$ is a suitable candidate for microwave passive component applications.

\section{Acknowledgements}

Financial supports of the National Natural Science Foundation of China (Grant No. 11464006) and the Middle-aged and Young Teachers in Colleges and/or Universities in Guangxi Basic Ability Promotion Project of China (Grant No. KY2016YB534) are gratefully acknowledged by the authors.

\section{References}

[1] Wersing W. Microwave ceramics for resonators and filters. Current Opinion in Solid State and Materials Science 1996, 1: 715-731.

[2] Bolton RL. Temperature compensating ceramic capacitors in the system barium-rare earth oxide titania. Ph.D. Thesis. The University of Illinois, 1968.

[3] Sremoolanathan H, Sebastian MT, Pezholil M. Dielectric resonators in $\mathrm{BaO}-\mathrm{Ln}_{2} \mathrm{O}_{3}-5 \mathrm{TiO}_{2}$ system $(\mathrm{Ln}=\mathrm{La}, \mathrm{Pr}, \mathrm{Nd}$, Sm). British Ceramic Transactions 1996, 95: 79-81.

[4] Ohsato $H$. Science of tungstenbronze-type like $\mathrm{Ba}_{6-3 x} R_{8+2 x} \mathrm{Ti}_{18} \mathrm{O}_{54}(R=$ rare earth) microwave dielectric solid solutions. J Eur Ceram Soc 2001, 21: 2703-2711.

[5] Valant M, Suvorov D, Rawn CJ. Intrinsic reasons for variations in dielectric properties of $\mathrm{Ba}_{6-3 x} R_{8+2 x} \mathrm{Ti}_{18} \mathrm{O}_{54}(R=$ LA-Gd) solid solutions. Jpn J Appl Phys 1999, 38: 2820.

[6] Varfolomeeva MB, Miranov AS. The synthesis and homogeneity ranges of the phases $\mathrm{Ba}_{6-3 x} \mathrm{Ln}_{8+2 x} \mathrm{Ti}_{18} \mathrm{O}_{54}$. Russ J Inorg Chem 1988, 33: 607.

[7] Kolar D, Skapin SD, Suvorov D. Phase equlibria in the system $\mathrm{BaO}-\mathrm{TiO}_{2}-\mathrm{Gd}_{2} \mathrm{O}_{3}$. Acta Chimica Slovenica 1999 , 46: 193-202.

[8] Kolar D, Gaberšček S, Stadler Z, et al. High stability, low loss dielectrics in the system $\mathrm{BaO}-\mathrm{Nd}_{2} \mathrm{O}_{3}-\mathrm{TiO}_{2}-\mathrm{Bi}_{2} \mathrm{O}_{3}$. Ferroelectrics 1980, 27: 269-272.

[9] Ohsato H, Ohhashi T, Kato H, et al. Microwave dielectric properties and structure of the $\mathrm{Ba}_{6-3 x} \mathrm{Sm}_{8+2 x} \mathrm{Ti}_{18} \mathrm{O}_{54}$ solid solutions. Jpn J Appl Phys 1995, 34: 187-191.

[10] Yao X, Lin H, Zhao X, et al. Effects of $\mathrm{Al}_{2} \mathrm{O}_{3}$ addition on the microstructure and microwave dielectric properties of
$\mathrm{Ba}_{4} \mathrm{Nd}_{9.33} \mathrm{Ti}_{18} \mathrm{O}_{54}$ ceramics. Ceram Int 2012, 38: 6723-6728.

[11] Ohsato H, Mizuta M, Ikoma T, et al. Microwave dielectric properties of tungsten bronze-type $\mathrm{Ba}_{6-3 x} R_{8+2 x} \mathrm{Ti}_{18} \mathrm{O}_{54}(R=$ La, Pr, Nd and Sm) solid solutions. J Ceram Soc Jpn 1998, 106: 178-182.

[12] Pei J, Yue Z, Zhao F, et al. Effects of silver doping on the sol-gel-derived $\mathrm{Ba}_{4}\left(\mathrm{Nd}_{0.7} \mathrm{Sm}_{0.3}\right)_{9.33} \mathrm{Ti}_{18} \mathrm{O}_{54}$ microwave dielectric ceramics. J Am Ceram Soc 2007, 90: 3131-3137.

[13] Ubic R, Reaney IM, Lee WE, et al. Properties of the microwave dielectric phase $\mathrm{Ba}_{6-3 x} \mathrm{Nd}_{8+2 x} \mathrm{Ti}_{18} \mathrm{O}_{54}$. Ferroelectrics 1999, 228: 271-282.

[14] Huang X, Zhang J, Wang W, et al. Effect of $\mathrm{pH}$ value on electromagnetic loss properties of Co-Zn ferrite prepared via coprecipitation method. J Magn Magn Mater 2016, 405: 36-41.

[15] Huang X, Zhang J, Xiao S, et al. Unique electromagnetic properties of the zinc ferrite nanofiber. Mater Lett 2014, 124: 126-128.

[16] Sebastian MT. Dielectric Materials for Wireless Communication. Elsevier, 2010.

[17] Nagatomo T, Otagiri T, Suzuki M, et al. Microwave dielectric properties and crystal structure of the tungstenbronze-type like $\left(\mathrm{Ba}_{1-\alpha} \mathrm{Sr}_{\alpha}\right)_{6}\left(\mathrm{Nd}_{1-\beta} \mathrm{Y}_{\beta}\right)_{8} \mathrm{Ti}_{18} \mathrm{O}_{54}$ solid solutions. J Eur Ceram Soc 2006, 26: 1895-1898.

[18] Zhu J, Kipkoech ER, Lu W. Effects of $\mathrm{LnAlO}_{3}(\mathrm{Ln}=\mathrm{La}, \mathrm{Nd}$, $\mathrm{Sm})$ additives on the properties of $\mathrm{Ba}_{4.2} \mathrm{Nd}_{9.2} \mathrm{Ti}_{18} \mathrm{O}_{54}$ ceramics. J Eur Ceram Soc 2006, 26: 2027-2030.

[19] Zheng H, Reaney IM, Muir D, et al. Effect of glass additions on the sintering and microwave properties of composite dielectric ceramics based on $\mathrm{BaO}-\mathrm{Ln}_{2} \mathrm{O}_{3}-\mathrm{TiO}_{2}$ $(\mathrm{Ln}=\mathrm{Nd}$, La). J Eur Ceram Soc 2007, 27: 4479-4487.

[20] Jacob KS, Satheesh R, Ratheesh R. Preparation and microwave characterization of $\mathrm{BaNd}_{2-x} \mathrm{Sm}_{x} \mathrm{Ti}_{4} \mathrm{O}_{12}(0 \leqslant$ $x \leqslant 2$ ) ceramics and their effect on the temperature coefficient of dielectric constant in polytetrafluoroethylene composites. Mater Res Bull 2009, 44: 2022-2026.

[21] Xia H-T, Kuang X-J, Wang C-H, et al. Conductivity and dielectric loss of tungsten-bronze-type $\mathrm{BaNd}_{2} \mathrm{Ti}_{4} \mathrm{O}_{12}$ microwave ceramics. Acta Phys-Chim Sin 2011, 27: 2009-2014.

[22] Wu M-C, Hsieh M-K, Yen C-W, et al. Low sintering $\mathrm{BaNd}_{2} \mathrm{Ti}_{4} \mathrm{O}_{12}$ microwave ceramics prepared by $\mathrm{CuO}$ thin layer coated powder. J Eur Ceram Soc 2007, 27: 2835-2839.

[23] Long M, Zhuang W, Tang B, et al. Microwave dielectric properties of $\mathrm{Ba}_{0.75} \mathrm{Sr}_{0.25}\left(\mathrm{Nd}_{x} \mathrm{Bi}_{1-x}\right)_{2} \mathrm{Ti}_{4} \mathrm{O}_{12}$ solid solutions. Ceram-Silikáty 2011, 55: 373-377.

[24] Long M, Zhuang W, Tang B, et al. Effect of molar ratio of $\mathrm{Nd} / \mathrm{Bi}$ on the microwave ceramic properties of $\mathrm{Ba}_{0.75} \mathrm{Sr}_{0.25}\left(\mathrm{Nd}_{x} \mathrm{Bi}_{1-x}\right)_{2} \mathrm{Ti}_{4} \mathrm{O}_{12}$ microwave materials. Piezoelectrics \& Acoustooptics 2012, 34: 106-109. (in Chinese)

[25] Zhang Y-D, Zhou D, Guo J, et al. Microwave dielectric properties of the $(1-x)\left(\mathrm{Mg}_{0.95} \mathrm{Zn}_{0.05}\right) \mathrm{TiO}_{3}-x\left(\mathrm{Ca}_{0.8} \mathrm{Sm}_{0.4 / 3}\right)$ $\mathrm{TiO}_{3}$ temperature stable ceramics. Mater Lett 2014, 32: 200-202.

[26] Pang L-X, Zhou D, Cai C-L, et al. Infrared spectroscopy 
and microwave dielectric properties of ultra-low temperature firing $\left(\mathrm{K}_{0.5} \mathrm{La}_{0.5}\right) \mathrm{MoO}_{4}$ ceramics. Mater Lett 2013, 92: 36-38.

[27] Zhou H, Liu X, Chen $\mathrm{X}$, et al. $\mathrm{Ba}_{4} \mathrm{LiNb}_{3-x} \mathrm{Sb}_{x} \mathrm{O}_{12}$ : Phase evolution, microstructure and optimized microwave dielectric properties. Mater Lett 2013, 96: 199-202.

[28] Wang X, Fu R, Chen X. Crystal structure and microwave dielectric properties of $\left(\mathrm{Ba}_{1-\alpha} \mathrm{Sr}_{\alpha}\right) \mathrm{Sm}_{2} \mathrm{Ti}_{4} \mathrm{O}_{12}$ solid solutions. J Mater Sci: Mater El 2016, 27: 11137-11141.

[29] Webhoffer A, Feltz A. Microwave dielectric properties of ceramics of the system $\mathrm{Ba}_{6-x}\left(\mathrm{Sm}_{y} \mathrm{Nd}_{1-y}\right)_{8+2 x / 3} \mathrm{Ti}_{18} \mathrm{O}_{54}$. J Mater Sci Lett 1999, 18: 719-721.

[30] Kagomiya I, Suzuki M, Kakimoto K, et al. Microwave dielectric properties of tungsten bronze type like $\left(\mathrm{Ba}_{1-\alpha} \mathrm{Sr}_{\alpha}\right)_{6-3 x} \mathrm{R}_{8+2 x} \mathrm{Ti}_{18} \mathrm{O}_{54}(\mathrm{R}=\mathrm{Sm}, \mathrm{Nd})$ solid solutions. $J$ Eur Ceram Soc 2007, 27: 3059-3062.

[31] Huang $\mathrm{X}$, Chen $\mathrm{Y}, \mathrm{Yu} \mathrm{J}$, et al. Fabrication and electromagnetic loss properties of $\mathrm{Fe}_{3} \mathrm{O}_{4}$ nanofibers. J Mater Sci: Mater El 2015, 26: 3474-3478.

[32] Huang X, Zhang J, Liu Z, et al. Facile preparation and microwave absorption properties of porous hollow $\mathrm{BaFe}_{12} \mathrm{O}_{19} / \mathrm{CoFe}_{2} \mathrm{O}_{4}$ composite microrods. J Alloys Compd
2015, 648: 1072-1075.

[33] Melvin GJH, Ni Q-Q, Natsuki T. Electromagnetic wave absorption properties of barium titanate/carbon nanotube hybrid nanocomposites. J Alloys Compd 2014, 615: 84-90.

[34] Zheng XH, Chen XM. Dielectric ceramics with tungsten bronze structure in $\mathrm{BaO}-\mathrm{Nd}_{2} \mathrm{O}_{3}-\mathrm{TiO}_{2}-\mathrm{Nb}_{2} \mathrm{O}_{5}$ system. J Mater Res 2002, 17: 1664-1670.

[35] Shannon RD. Revised effective ionic radii and systematic studies of interatomic distances in halides and chalcogenides. Acta Cryst 1976, A32: 751-767.

[36] Chen XM, Li Y. A- and B site cosubstituted $\mathrm{Ba}_{6-3 x} \mathrm{Sm}_{8+2 x} \mathrm{Ti}_{18} \mathrm{O}_{54}$ microwave dielectric ceramics. $\mathrm{J} \mathrm{Am}$ Ceram Soc 2002, 85: 579-584.

Open Access The articles published in this journal are distributed under the terms of the Creative Commons Attribution 4.0 International License (http://creativecommons. org/licenses/by/4.0/), which permits unrestricted use, distribution, and reproduction in any medium, provided you give appropriate credit to the original author(s) and the source, provide a link to the Creative Commons license, and indicate if changes were made. 